慶應義塾大学学術情報リポジトリ

Keio Associated Repository of Academic resouces

\begin{tabular}{|c|c|}
\hline Title & Studies of the development of optical fiber sensors for biochemical analysis \\
\hline \multicolumn{2}{|l|}{ Sub Title } \\
\hline Author & $\begin{array}{l}\text { 高井, 信治(Takai, Nobuharu) } \\
\text { 佐久間, 一郎(Sakuma, Ichiro) } \\
\text { 福井, 康裕(Fukui, Yasuhiro) } \\
\text { 金子, 明子(Kaneko, Akiko) } \\
\text { 藤江，忠雄(Fujie, Tadao) } \\
\text { 田口，一宏(Taguchi, Kazuhiro) } \\
\text { 長岡, 昭二(Nagaoka, Shoji) }\end{array}$ \\
\hline Publisher & 共立薬科大学 \\
\hline Publication year & 1991 \\
\hline Jtitle & $\begin{array}{l}\text { 共立薬科大学研究年報 (The annual report of the Kyoritsu College of } \\
\text { Pharmacy). No.36 (1991. ), p.68- } 68\end{array}$ \\
\hline \multicolumn{2}{|l|}{ JaLC DOI } \\
\hline \multicolumn{2}{|l|}{ Abstract } \\
\hline Notes & 抄録 \\
\hline Genre & Technical Report \\
\hline URL & $\begin{array}{l}\text { https://koara.lib.keio.ac.jp/xoonips/modules/xoonips/detail.php?koara_id=AN00062898-0000003 } \\
\text { 6-0068 }\end{array}$ \\
\hline
\end{tabular}

慶應義塾大学学術情報リポジトリ(KOARA)に掲載されているコンテンツの著作権は、それぞれの著作者、学会または出版社/発行者に帰属し、その権利は著作権法によって 保護されています。引用にあたっては、著作権法を遵守してご利用ください。

The copyrights of content available on the KeiO Associated Repository of Academic resources (KOARA) belong to the respective authors, academic societies, or publishers/issuers, and these rights are protected by the Japanese Copyright Act. When quoting the content, please follow the Japanese copyright act. 


\title{
Studies of the Development of Optical Fiber Sensors for Biochemical Analysis*
}

\author{
N. Takai ${ }^{* *}$, I. Sakuma***, Y. Fukui***, A. Kaneko, T. Fujie, \\ K. TAGUCHI $* * * *$, and S. NAGAOKA $* * * *$ \\ 高井信治**, 佐久間一郎 ${ }^{* * *}$, 福井康裕 ${ }^{* * *}$, 金子明子, 藤江忠雄, \\ 田口一宏****, 長岡昭二****
}

Abstract: An optical fiber sensor utilizing Thymol blue and an ion-exchange resin complex in a cellulose acetate membrane was developed. By monitoring several different chromophores of Thymol blue, the sensor could measure the $\mathrm{pH}$ of the solution from 1.0 to 12.0 with good reproducibility. An optical fiber glucose sensor utilizing a cellulose acetate membrane containing glucose oxidase, 2,7-diaminofluorene dihydrochloride, and sodium $N$-(3-sulfopropyl) -3,3"-5,5'-tetramethylbenzidine was developed. Reflectance, changes at $580 \mathrm{~nm}$ were large enough to trace changes in glucose concentration in physiological saline solution. Key Words: Optical fiber sensor.

* 本報告は Artifical Organs, 15 (2)，86-89（1991）に発表.

** 東京大学生産技術研究所

*** 東京電譏大学

**** 東レ基礎研究所 